\title{
Concept of Cultural Teaching in Serat Dewaruci by Yasadipura I
}

\author{
Iis Purnengsih $^{1^{*}} \quad$ Dharsono $^{2^{*}} \quad$ Agung Eko Budi W ${ }^{3^{*}} \quad$ Suyanto $^{4^{*}}$ \\ 1.Doctoral program students of Arts, Institut Seni Indonesia Surakarta, Indonesia \\ 2.Professor of Institut Seni Indonesia Surakarta, Indonesia \\ 3.Faculty of Fine Arts and Design, Institut Teknologi Bandung, Jawa barat, Indonesia \\ 4.Faculty of Pedalangan Department, Institut Seni Indonesia Surakarta, Indonesia
}

\begin{abstract}
This article focuses on discussing the concept of cultural teachings implicit in the Serat Dewaruci by Yasadipura I. Cultural teachings are teachings about the search for true knowledge. The purpose of this paper is to describe the journey of Bima (as personification) to meet Dewaruci (inter-personification), in finding holy water perwitasari (water of life), and discovering cultural teachings. The steps of the research / study carried out with a qualitative research model with a Javanese culture approach, referring to the teachings of Javanese culture in accordance with the philosophy and philosophy of Javanese culture. The analysis resulted in a description of Bima's journey (as personification) meeting Dewaruci (inter-personification), in finding holy water perwitasari (water of life), and discovering cultural teachings, namely: the Tri-loca teachings, the Astagina teachings and the Hastabrata teachings.
\end{abstract}

Keywords: Concept, culture teaching, serat Dewaruci, Yasadipura I.

DOI: $10.7176 / \mathrm{ADS} / 84-03$

Publication date:August $31^{\text {st }} 2020$

\section{Introduction}

The Dewaruci story is a popular suluk in Java and is often played as a shadow puppet story. The diversity of versions shows the extent of the spread of this story, as well as the many texts that contain the text of this story in various museums at home and abroad. For a long time quite a number of Javanese literary scholars have examined it, based on the consideration that this suluk is the best representation of Javanese mysticism. In it the philosophy of Javanese life based on syncretic forms of spirituality or mysticism is clearly illustrated. The famous version is the composition of Raden Ngabehi Yasadipura I, Surakarta poet who lived during the reign of Pakubuwana II (1726-1749 AD) and Pakubuwana III (1749-1788 AD). Yasadipura I wrote his suluk in the framework of Javanese cultural and literary renaissance (Echols and Pigeaud 1969). It was during this period that the synergy of Javanese and Islamic culture, represented by tasawuf or Sufism, took its definitive form. Sinthesa is fully reflected in the Dewaruci story.

Serat Dewaruci by Yasadipura I (1729-1801), is a literary work (poetic form) in the song of macapat, which illustrates the fame of the Bima figure in seeking holy water perwitasari (living water), and producing wirid ${ }^{1}$ in true science. Cultural teachings ${ }^{2}$ about guidance on the search for true knowledge, and these teachings have their roots in the lives of Javanese people in the form of philosophical reflections. The contemplation in serat Dewaruci is "Filsafat Mistika" (Mystical Philosophy) which is obtained not through punishment, received through "penghayatan batin" (inner experience) by way of samadi (meditation). In the consciousness of samadi consciousness (a changing or conclusive meditative state) man acquires "pengetahuan penghayatan" (experiential knowledge). This knowledge is contained in the story of Bima's journey to find air of life. Bima climbed the mountain, entered the samodera to meet Dewaruci and entered inside, finally seeing an ivory doll. This all thinks (ego) overcomes my consciousness (ego conciousness), enters the unconscious, unites with the person (self) and acquires knowledge by seeing the nature of life as a puppet. Illustrated here is the transcendental process and the transdence from ego or sensory awareness to personal conscience and finally reaching the divine consciousness or the universe (Divine or Cosmic consciousness). This whole process becomes an experience of knowledge and is poured into conceptual knowledge in the anthropology and epistomology of mysticism (mystical anthropology and epistomology). The Candra of the human soul (human image) cannot stop at any time, but can be changed by changing oneself into a person and there is Renewal (Self - Absolute Being). Complete knowledge (absolute knowledge) is obtained by the unity of subject and object (the union of subject and object) (Ciptoprawiro 1986: 41-42).

\footnotetext{
${ }^{1}$ Wirid, that is, as a condition or key to entering True Science, in which the explanation contains suggestions for monotheistic or non-shirk behavior in behavior, as well as patience, trust, and other Sufistic morals, true science schools can be characterized as cultural movements that support Sufistic moral cultural education or Practical morals. Although not as a study of special relations, this can be seen from the general relation of the similarity of terms such as patience, tawakal, and several other moral terms found in reminder lessons for students of the True Science College (Nurul Huda, 2017).

${ }^{2}$ cultural teachings in the Javanese perspective teach humans about virtue, virtues, glories, virtues, morality (ethics) of life that comes from the divine value to achieve self-perfection, and the principle of order in the cosmos becomes the core of cultural outreach (Darmoko, 2020)
} 


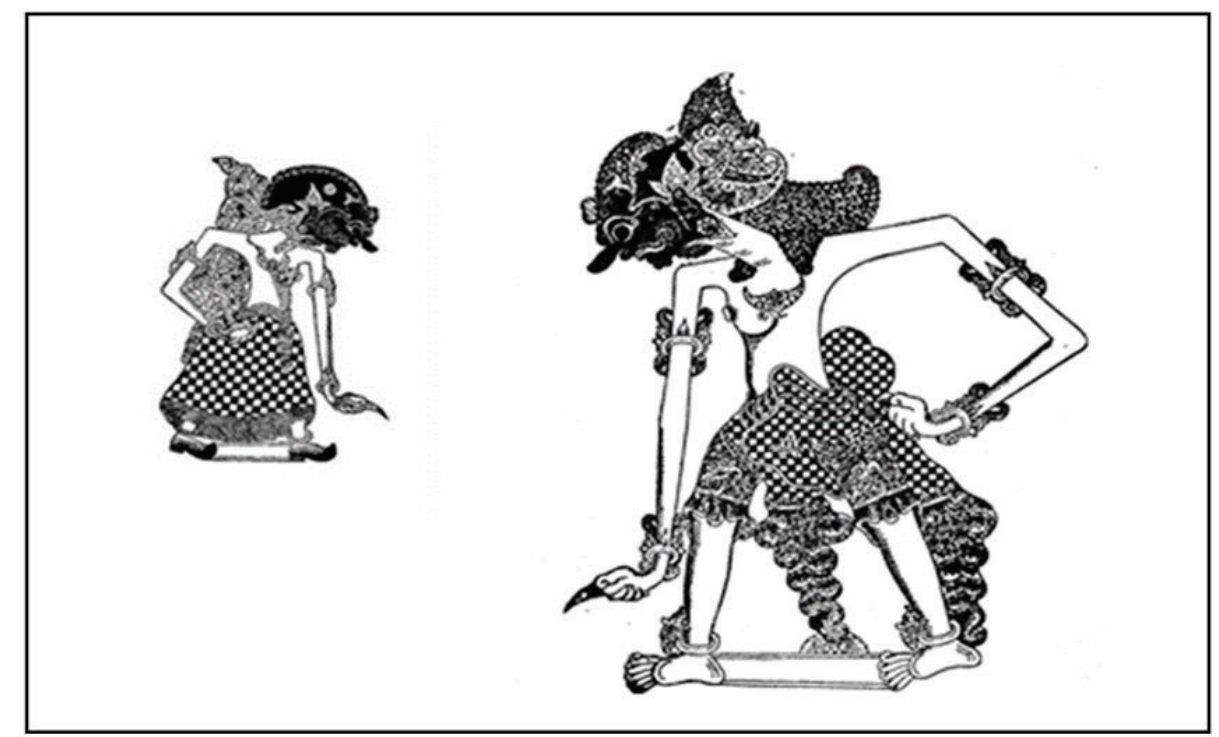

Figure 1: Bima as the personification and Dewaruci is inter-personified, the journey is told, Bima climbed a mountain, entered the ocean, and met with Dewaruci and entered his body, finally getting an ivory doll (filled with spirit in true science). This all illustrates: I (the ego) overcome my consciousness (ego consciousness), enter the unconscious (the conscious), unite with the person (the Self) and gain knowledge by seeing the nature of life as an ivory puppet (Dharsono 2016: 178).

Aesthetics that are built through these literary works, emphasize the combination of the beauty of song literature with the teachings of goodness. Teachings that describe the wandering of the human mind in searching for the essence of human life. Humans in achieving true kasampurnan are faced with seven levels of testing towards the highest level of life called the Niskala realm (the upper realm in cultural teachings about Tri-loca / Tri-buana). Javanese people realize that life in the world is only false, so they look for real life (true life). During the world needs to be equipped to enter into real life, then humans must purify themselves physically and mentally (Dharsono 2007: 128).

Javanese people realize that life in the world is only false, so they look for real life (true life). During the world needs to be equipped to enter into real life, then humans must purify themselves physically and mentally. These cultural teachings, differ from the teachings contained in Western philosophy which is frahmentary. If Western philosophy always questions logically about life, then the philosophical philosopher questions about the search for life's journey in achieving purity. When we use Javanese in our own language, philosophy means: "ngudi kasampurnan" (trying to find true kasampurnan). The Greek philosophia should be read in Javanese as "ngudi kawicaksanan" (trying to gain intelligence). The two philosophical reflections above, provide information that a series of aesthetic forms of the archipelago (Java) are implemented through symbolic language, which was born from searching through an approach to the universe. It is not surprising that the classical society at that time in its efforts to get closer to God, namely by getting closer to the universe. So that there is a relationship between himself (microcosm) with the universe and its environment (macrocosm) and the relationship between him and his God (metacosm) (Dharsono 2007: 130).

Javanese views in seeing, understanding, and behaving are also oriented towards source culture. The process of Javanese culture is in harmony with the dynamics of society which refers to the concept of the main culture, namely "sangkan paraning dumadi" (Geertz 1981: X-XII). Birth and / or existence due to the relationship between man and his God through the process of birth, life and life, all of which occur by the existence of cause and effect. Geertz links the problem to some use of the term in Javanese religion ${ }^{1}$ which is based on the main principle called "sangkan paraning dumadi". This concept in Javanese culture is known as nunggak semi ${ }^{2}$.

The substance of Dewaruci's teachings to Bima is the virtue of Javanese spiritual life which has content of

\footnotetext{
${ }^{1}$ The emergence of the term Javanese Religion which is interpreted as ancestor worship (Cliford 1981), has been straightened out by Harsja Bachtiar, based on Javanese research in Suriname (1976), that what is actually meant by Javanese Religion is not ancestor worship, but is rooted in the main principle called : please paraning dumadi. Important issues, Cliford or Harsja Bachtiar are able to provide information about the religious system in Javanese social life in the map of cultural life relating to the relationship between social structures that exist in society, relations between organizing systems and the embodiment of symbols (Cliford 1981: X-XII).

${ }^{2}$ Nunggak semi $=$ from the origin of the word arrears which means the rest of the trunk with roots left in the ground, semi meaning buds or sprout growth Spring can be interpreted as a growth of the parent culture (the arrears). A process of change (development) of a cultural behavior, then at a certain phase still refers to the parent culture (baboon). The form of life tree is the result of the process of cultural development, which traditionally refers to the essence of culture (Harjonegoro, 15 June 1999).
} 
laku ${ }^{1}$, ngelmu, doubtful, and incomprehensible to emphasize oneself to be closer to God (unity). The acquisition of knowledge in the process of learning culture is used as a provision to reach a world order that is safe, peaceful, peaceful and prosperous (mamayu hayuning bawana). The behavior described in the Serat Dewaruci can be understood as a form of life attitude to achieve the desired goal. The main thing to understand, that behavior is a spiritual form of man. Spiritual is an infinite form of trust and can be simplified as trust in Him. To the absolute and singular. Javanese spiritual culture has a phrase related to this, namely "Sangkan Paraning Dumadi", which centers on "Kawula Gusti". "Sangkan Paraning Dumadi" means the base or origin and direction of all events, which describe a philosophy of process, the continuity of the beginning, how or where it began, as well as the end. As revealed from the words: Guru will, Guru dadi ". The process of "dumadi" which has the meaning of actualizing potential. Behind the process will get His statement revealed through events, so that each event actually takes part in the process of actualizing the potential (Supadjar 2001).

The teaching of "Sangkan Paraning Dumadi" according to Franz Magnis Suseno is the core of the Serat Dewaruci, and also as an expression of the teachings of "Kawula Gusti" to the closest distance (Supadjar 2001: 67). This teaching is expected to be practiced as a guide to daily practical life, so that the concept of human behavior becomes increasingly apparent in harmony. The concept of social harmonization in Javanese culture is a Javanese identity is the result of a long process, through qualitative selection, which is related to life values. The concept of harmony was revealed through statements: Sangkan Paraning Dumadi, Hamemayu Hayuningrat, Pamoring Kawula Gusti; all of it is a special metaphysics of God, cosmological and anthropological. The Javanese outlook on life implies a process philosophy, which is meant here is God as Pandoming Dumadi, as well as cosmological matters, the universe as Pandoming Dumadi. On social humanitarian issues, the principle of wisdom revealed through words is Pandoming Dumadi (Supadjar 2001: 266). This shows that everything has a clear benchmark, so that it can be used as a form of reminder of human behavior.

The teachings of Javanese philosophy implicitly explain the micro-macro-metacosm relationship, according to the mystical culture of Indonesia's thinking system. The view of the macrocosm seated man as part of the universe. Humans must be aware of their place and position in the universe. The view of micro-meta-macrocosm, in a concept that came to be called the teachings of Tribuana / Tri-loca, namely; (1) the niskala realm (the unseen and not perceptible nature), (2) the niskala sakala realm (natural and immoral nature, sensed but also indifferent, and (3) the natural realm (underworld). Humans can move to the three metacosmic realms through the niskala sakala (middle nature) and niskala (upper realm), the public's view of the relationship between microcosm and macrocosm, the concept of "mandala" forms a balance, harmony and unity and each gives strength / energy centrally life) The form of ritual in the concept of mandala is the concept of the interaction of relationships which then forms a unity and balance of the cosmos "Centering." The concept of "mandala" forms a balance, harmony and unity that each gives strength / energy centrally (centering of life) (Arguelles 1972: 85).

The fame of the Bima figure, who in searching for living water and obtaining wirid in true science, can be used as an indication of how this effort has indeed taken root in the lives of Javanese people (Bima, die op zoek naar het levenswater de inwijding in de hoogste kennis en het ware inzincht ontvangt, right hier een aanwijzing zijn, hoezeer in de Javaan dit striven ingerworteld ligt) (Ciptoprawiro 1986:11). For Javanese people, life in the world is only apparent, so they look for real life (true life). And while in the world need to be equipped to enter into real life, then humans must purify themselves physically and mentally.

The focus of this article study discusses the concept of cultural teachings implicit in serat Dewaruci by Yasadipura I. More deeply, this article discusses the concepts of the Tri-loca, Astagina and Hastabrata teachings implied in the story of Bima's journey in search of holy water perwitasari. The scientific article is titled 'The Concept of Cultural Teachings Implied in the Serat Dewaruci by Yasadipura I. In this article explains how the concept of cultural teachings is implied in the story of Bima's journey to find Perwitasari holy water.

Cultural teachings in Serat Dewaruci need to be studied, because these teachings are part of the cultural expression of Javanese people. Cultural teaching is one of the nation's cultural heritages not an obsession to take our society back to the corridors of past history or discover the past, but rather to find her own identity. He is not a nation that was born from the fragments of human culture, but from an estuary of this nation. This historical belief psychologically will not only provide pride, but also loyalty to maintain and manipulate the noble values and great traditions of the people. That means the national culture that is built must be able to function as an instrument that accommodates the present and opens the door to the future. So far there has been no article that discusses the concept of cultural teaching in Serat Dewaruci by Yasadipura I specifically.

The purpose of this paper is:

- Describe Bima's journey (as personification) to meet with Dewaruci (inter-personification), in searching for holy water perwitasari (water of life).

\footnotetext{
${ }^{1}$ Laku derived from the Javanese language, has the meaning of the way to achieve noble goals with determination. Behavior can only be done by proceeding to become, so that people who practice it always have a process to improve themselves by doing good things to achieve eternal goals. The things emphasized in the concept of behavior are sincerity by prioritizing harmony and harmony of nature both microcosm and macrocosm (Damardjati, 2001)
} 
- $\quad$ Describe the teachings implicit in the journey "Bima in search of holy water perwitasari" in the Serat

Dewaruci by Yasadipura I.

The comments concerning the analysis in this study put more emphasis on the interaction model of qualitative data analysis, using the Javanese culture approach. Interaction analysis is done to analyze qualitative data from empirical data collection results. To get accurate results from classification by identification and identification. This model was chosen because it makes it possible to provide a greater number of scans that can capture input and exposure in summaries that are data reduction and inference. The model used in analyzing qualitative data by applying a cycle system, means that researchers are always moving and exploring.

The interactive results of the analysis are then reviewed by interpretive analysis hermeneutically. Hermeneutics refers to the interpretation of expressions that are meaningful and intentionally done by humans. Interpreting interpretations that have been carried out by individuals or groups of people of their own situation. Every event or work has meaning from the interpretation of the actors or the makers. The work which is the result of the interpretation then faces the reader or observer and is captured with the interpretation as well. In a hermeneutic analysis, the researcher interprets the work as if the work was re-created as a new meaning, in accordance with the cultural theory used (Sutopo 2002). Hermeneutics raises the issue of how to arrive at what is expressed. Therefore hermeneutics is formulated as a theory of understanding operations in relation to cultural interpretation as a text. Interpretation is emphasized as the distinction of a meaning that is hidden in the visible meaning. The task of the hermeneutic is to recognize the origin of the text or the world of the text or reality which is spoken by the text and not the soul of the creator (Poespoprodjo 1991: 117-118).

\section{Discussion}

\subsection{Bima's journey in finding holy water perwitasari.}

The Bimasuci story, often also called the Dewaruci story, tells the story of Bima's adventure to obtain the holy water of Tirtaprawitra at the direction of his teacher, Sri Dangnyang Drona. Holy water has the property to cleanse people's souls, so that they become perfect and pure human beings. After Bima struggled to find the holy water, finally met Dewaruci. Then from Dewaruci Bima get an explanation of what is meant by the holy water. According to Dewaruci, the holy water that Bima is looking for is a true form, a wise form, and has the character to color the whole life, not seen, because without form, without color, without form, without being seen, without direction, and without place, there is only in he who is wary of responding to untouchable addresses, which fills this realm (S.P Adhikara 2011: 2).

The story of Bimasuci as a whole is a picture of a human child named Bima, who is introspective. Basically introspective is remembering personal life, from the time a child is still up to the time he introspected. All of his life experiences, recorded in the unconscious (subconsciousness). Looking back, it's as if he saw a play with the director, screenwriter, main role. And the audience themselves. As for the story played by the introspective, it is likened to being put on trial, so he acts as a defendant, lawyer, prosecutor, and judge as well. The purpose of introspective is to improve personal life in the future. Introspective people must be honest in assessing their behavior in the past, as well as knowing their personal blemishes and the limits of their ability to lead life in the universe. In other words, the introspective is like confessing his own personal sin. Among Sufism experts in the Middle East, introspection is a very important job in worshiping God Almighty.

The relationship between humans and their peers is still an actual problem, because the problem is universal and has not yet obtained a satisfactory solution. In the Bimasuci fiber of Ysadipura I poet's literary works, the problem was also revealed to be resolved. The relationship between humans and their masters in this literary work is presented by likening human beings as shadow puppets, while God as the puppeteer in shadow puppet performances. The words are delivered in the form of poems and stems. In the poet Yasadipura I addressed to his readers, God is likened to assume, the human body is likened to shadow puppets, the human soul is described as the permana, which acts as a puppeteer, the public is expressed as spectators of shadow puppets, and shadow puppets are wholly considered natural universe of everything.

When Bima received orders from Drona Receipt to meditate on the water's edge. In that place Bima established tapa and after mastering and controlling his mind, he died of death by extinguishing his five senses, so he was cut off from the outside world. In a state of physical death Bima is in a realm that is not supported by space and does not carry the time, which is the mental realm. Bima did the kind of tapa science of "introspective", with the aim that he had a body and soul that is holy, so he deserves to be called Bimasuci. In the mental realm, Bima imagined himself as a child, so Bima Katik, who was still at this stage. The Bima's who was imprisoned, so the Bima's Hermit was already at the Ego level, because he had finished studying the Drona Receipt. After the Bima's hermit conversed briefly with Bima Katik, the Hermit Hermit imagined that Bima's Katik was already at the superego level, namely the highest level of human life which the Poet Yasadipura I called Dewaruci called. Before Bima's hermit received advice from Bima Katik who was already at the superego level, the hermit Bima imagined Bima Katik when he was still a fetus, so the Bima fetus in the womb of Kunti's mother. Bima's hermit was amused, considering that he who was now like a mountain as big as a mountain, 
could be in the guagarba (womb) of his mother who was only as big as his pinky. When the Milky Hermit continued his imagery of how the Milky Fetus could enter into his mother's guagarba the imagery of the Milky Hermit collided with taboo (larangan), because his imagery was deemed inappropriate or dirty. In Javanese society the meaning of dirty, can be replaced with the idea of a small room can be called pekiwan which means characterized (left or soul in Javanese). So in freudian psychoanalysis, dreams or imaginations in the psychiatric realm that hit the taboo need to be held sensory, by way of transformation or change. Thus the imagery of the ascetic Bima above was changed by replacing the body hole of the mother Kunti who would be entered by the Bima Fetus with Dewaruci's left ear hole (S.P Adhikara 2011).

After Bima Fetus entered and arrived in the guagarba of Kunti's mother, he was confused because he did not know north south, west, east, top and bottom. In other words, Bima's way does not know the spatial layout. In addition, he also did not know "time" because in Kunti's mother's guagarba there was no sunlight. Space can be described by the arrangement of the cartesian axis x (north-south) y (west-east), and $\mathrm{z}$ (top-bottom), while the positive and negative parts can be expressed by the face and back of where Bima's way is. To find out the relative motion there needs to be other objects in Kunti's mother guagarba. So Yasadipura I overcome the problem of space and time in the Kunti's mother's guagarba by inserting the Bima Katik as Dewaruci into Kunti's mother's guagarba, along with the sun. In Serat Bimasuci the fragment is told in the Dandanggula song.

The breech behind the world (the universe) is the past nature. Thus the Poet Yasadipura I has stated, albeit in disguise, that the Bimasuci story tells about Bima's who founded the asceticism by introspective manner and aims to have a sacred body and soul, so that he can unite himself with the khalik. The Dewaruci's lecture was then held in guagarba, which can be interpreted, the Bima katik sermonize which was at the level of super ego to Bima Fetus, which was still at that early stage, took place in the guagarba of Kunti's mother. The ascetic who is at an ego level, listens to the lecture attentively.

The emphasis of the literary work "Serat Bimasuci", lies in Dewaruci's words to Bima. Dewaruci's speech was delivered when Bima saw four colors, namely black, red, yellow and white. According to Dewaruci in his discourse the four lights are called pancamaya or the reality of the heart is actually a bodily leader meaning that the heart is called the main trait that guides the good nature that is the true nature. As for red, black, yellow and white is a heart disaster. The contents of the world will be controlled by a three-colored heart that frustrates behavior, while those who can separate from it can unite with the unseen enemy of ascetics whose hearts are three black, red, and yellow, all blocking the mind and will that preserve unity with the soul noble. Pancamaya origin of the word "panca" which means "five" and "maya" which means "shadow". Then the Pancamaya can be interpreted as the image obtained between the senses stored, in the unconscious (heart). When the five senses respond to everything from the world around them, the senses are driven by lust. Lust that encourages the senses to carry out its function, by Dewaruci colored black, red, yellow and white. So thus there are four types of hearts, namely: black, red, yellow and white. How the nature of each heart, has been described by Dewaruci above the color of the heart that underlies every human action in living in this mortal world. Anyone who can control and control the four types of heart can reach one-alloyed servants and Khalik (manunggaling kawula Gusti).

Four colors of black, red, yellow and white disappear from vision Bima saw a flame that emitted eight colors. In this discourse, Dewaruci elaborates on the macrocosm (big world) and microcosm (small world). What is meant by macrocosm is the whole universe that can be responded to by the human senses. This sensory response, stored in the unconscious as Pancamaya, thus the universe exists in humans even though only as a shadow (maya). The contents of the universe are described as eight colors originating from one flame, the universe. The eight colors can be interpreted as eight main practices or $\mathrm{A} \mathrm{s} \mathrm{t} \mathrm{a} \mathrm{b} \mathrm{r} \mathrm{a} \mathrm{t}$ a. In the universe, the eight colors represent the sun, moon, stars, earth, sea, water, wind, and fire. In humans, as rnikrokosmos, the eight colors that describe the eight main practices, namely preserving life (sun), beauty (moon), obscene (star), patience (earth), the ability to bear joy and sorrow and solve problems of life (sea), purity (water), accuracy (wind), and completeness (fire) (S.P Adhikara 2011)(S.P Adhikara 2011a). Eight colors are no longer visible to Bima, he then sees a small object the size of a baby bee resembling a child made of ivory that emits blinding light.

The dazzling ivory is called Pramana, which means heart rate, so as long as the heart is still beating, during that human body is still alive. The body that supports pramana, while those who support pramana are called teak soul, who can feel the divine attributes of the Almighty in the human body and soul. If the human body dies, pramana also dies, but the souls of teak continue to live in nature that is not supported by space and does not carry time.

\subsection{The teachings implicit in Bima's journey in search of holy water perwitasari. 2.2.1 Bima's journey from the "Sakala Realm to" the Noetic Realm}

The teachings of the Javanese people in maintaining vertical and horizontal balance in Javanese culture are known as keblat papat kalima pancer, also called "the world of time", known by the classification of the four dimensions of space, patterned with four points of the wind with one center $(4+1)$. Together means the whole, 
the basic unity of opposition to control, meaning that the unity that occurs due to differences, and differences are the basis of strength that must be sought as a balance, harmony of life by means of self-control (Dharsono 2016). Related to the concept of metacosm, namely the concept of mandala; is a circle that symbolizes perfection, flawlessness, wholeness, completeness, and fulness of the universe which is essence, essence, unseen, inexpressible but omnipotent but Existing and Present. Presence is accommodated in the square space of the circle or essence in existence. The circle of the mandala is the cosmos, the order and order of the universe, the perfect harmony present in the previously chaotic rectangular space. The perfect is present in the world of defects, the light is present in the dark world, the supreme is present in the relative world, the orderly is present in the world of chaos, the men are present in the world of women, who are not visible in the visible world. Mandala is a totality of the elements of duality of existence. The upper world merges with the underworld through the middle-mandala world (Sumardjo 2003: 87).

Javanese people recognize the time system in the cosmos, is an inseparable relationship between himself and the universe. This view is recognized by the Javanese people as the fifth poetry keblat, in Javanese cosmogony; The earth (earth) is symbolized in black with the north showing lauwamah lust. Lauwamah lust means angongso (greedy), causing thirst, drowsiness, hunger and so on. Its place in the stomach, born from the mouth, is likened to a heart that shines black (Simuh 2019). Fire is symbolized in red with the southern direction of anger. Anger means to be fierce and have a temper of anger, envy, anger, and so on. Sourced in bile, arising from the ear, like a heart glowing red. The wind is symbolized in yellow with the west showing supiah lust; meaning lust, raises the character of longing, arouses desire, pleasure, and so forth comes from the spleen, arises from the eye, like a yellow glowing heart. Water is symbolized by the white color with the east is mutmainah (honest) meaning tranquility, has a temperament of goodness, without knowing the limits of ability, the source of bone, arising from the nose, like the heart shines white (Simuh 2019: 340). The center of the earth in the middle position symbolized by the green color is kama (mind), is a depiction of the subject of human inner desires. The five characteristics are in humans, so it depends on us, how to maintain balance or self-control (Subagyo 1981).

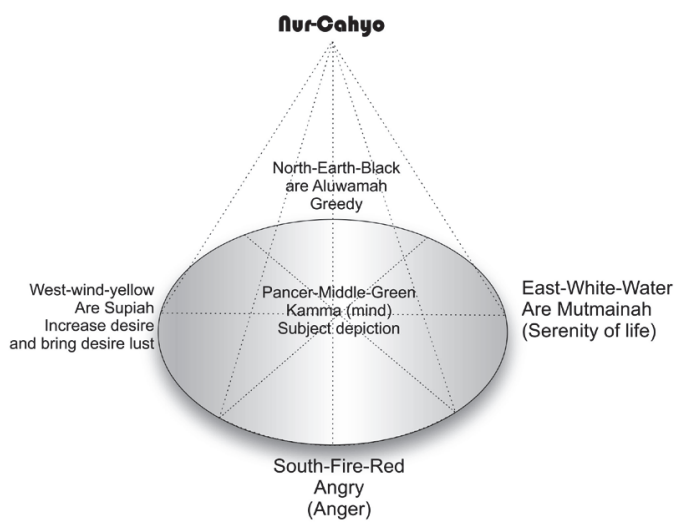

Figure 2: The concept of mandala: Numbers $4+1$ (keblat papat kalima pancer) dual concept of mandala $8+1$

(Hastagina) Self-control as a step to take true perfection. (Dharsono 2016: 200).

Humans will be able to achieve true kasampurnan, if humans are able to control themselves against the four passions in him, so that they will have a clairvoyant heart (watchful and always remember), and bring the gift of glory from Sangkan Paran (His will) (Hadiwijono 1974: 25).

The teachings of Javanese cosmogony give meaning, that the four human passions are essentially present in humans (microcosm), so that the symbols described will only gain meaning, if humans are able to control themselves. This nature of self-control in Javanese religion is called Nur-rasa, that is the basis of will (Nur) which drives the creation of sense (the will of the soul) and copyright of intention (culture) (Kartosoejono 1950:14-23). 


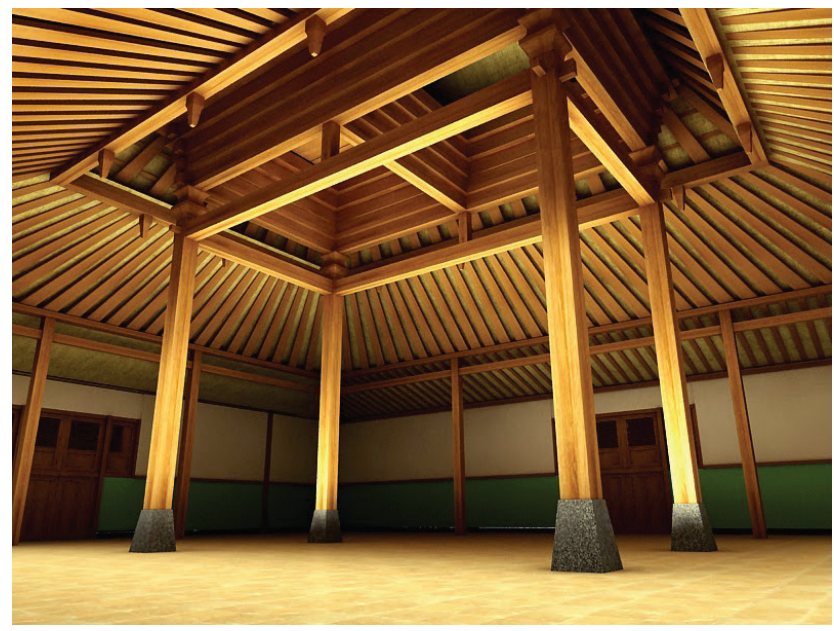

Figure 3: The teachings of Javanese cosmogony are implemented in four Sakagru,

(http://rudimayastoro.blogspot.com/2015 0201 archive.html, Purnengsih, 25 Juny 2020.

The realm of sakala (wadag realm, which is sensed), is depicted with 4 Sakaguru poles containing teachings on the control guidance of the 4 human passions. The view of the Javanese people in maintaining a vertical and horizontal balance in Javanese culture is known as the fifth glance training, also called "the world of time". Known as the fourth dimension of space, the four-point pattern with one center. Together means the whole, the basic unity of opposition to control, meaning that the unity that occurs due to differences, and differences are the basis of strength that must be sought as a balance, harmony of life by means of self-control.

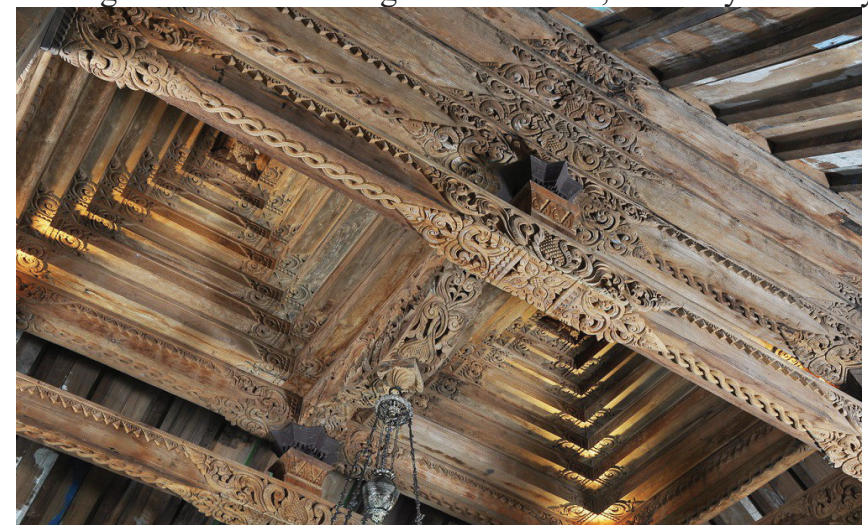

Figure 4: Seven (7) levels (intercropping) provide symbolism towards the noetic realm (http://rumahjoglonet.blogspot.com/2016/08/foto-rumah-joglo-jawa.html,

Purnengsih, 25 June 2020.

\subsubsection{Get the teachings of "Hastagina" in the concept of Mandala}

The Javanese people in their quest for a true kasampurnan are known by the teachings of "Hastagina" $(8+1)$. Javanese views in seeing the cosmological world of the lower world and the upper world, often combined with the middle world which is also called dualism dualism or dualism. The attitude of combining the two into one like that, in the environment of Javanese society called syncretism, the microcosm is human, macrocosm is the universe, while metacosm consists of the unseen realm (not sensed), the realms of wadag and tan wadag (sensed and uncensored) and the realm of sakala, namely wadag nature in this world (Sumardjo 2003).

The color symbolism in the teaching of "hastagina" has the same basis as the Javanese cosmogony symbolism of "the fifth glance of the blue" $(4+1)$, which is among the primary colors. The color is adjusted to the direction between the points of the compass, that is, between the main directions: east, south, west and north. Produces southeast, southwest, northwest and northeast. Among the main colors produce eight mixed colors, get a new character or trait as a blend of two main traits in color symbolism, namely; black, red, yellow, white, blue, green, violet, pink. The colors in the spectrum are emitted from white or bright colors, then called hastagina $(8+$ 1) double mandala teachings.

This is the reason why the center (pancer) is symbolized without color (empty), which in Javanese teaching is "empty" as a symbol of the Single Sahyang, in Hindu theology called the ruler of the Great Sahyang. The gods that are the symbol of each qibla / direction, are the gods created by the Great / Single Sahyang who are given power as the highest law of each direction / part of their duties, are symbols of the light of God (Nur-Rasa) like Dewa Agni masters fire, God Bayu controls the wind and so on. The centrum of why is empty (symbolized by no color), because empty (zero $=0$ ) symbolizes the absoluteness of God. His worship is always preceded by 
taking each direction starting with the East to South then towards the center (middle). Javanese tradition is associated with market days, starting with Legi (East), Paing (South), Pon (West), Wage (North), and Kliwon (Middle) in between. Bima's fame in seeking holy water "Perwitasari" (water of life), obtaining wirid in true science, can be used as an indication of how this effort has indeed taken root in the lives of Javanese people (by Yasadipura I, 1729-1801).

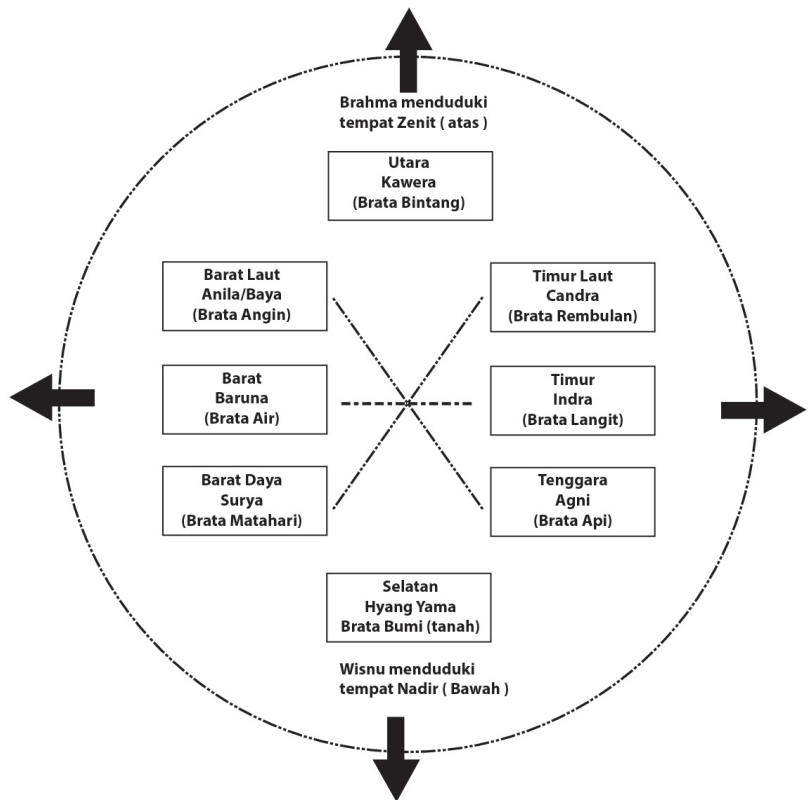

Figure 5: Concept Hastagina. (Dharsono 2016: 203).

\subsubsection{Getting the teachings of "Hastabrata" in the concept of Mandala.}

Hasthabrata's teachings were originally the teachings given by Rama to Wibisana (Wahyu Makutha Rama). Hastabrata is classified as a very old teaching, being introduced through wayang puppet. This teaching in the Serat Rama Jarwa Macapat is contained in the poem LXXVII Pangkur, the number of stanzas 35 pieces, Jasadipoera (in Marsono 2010). According to Budya Pradipta (Wahyati 1998) the Hasthabrata teachings were taken from the Book of Manawa Dharmasastra by Manu in India hundreds of years before Christ. The Hastabrata concept in the book implies that leaders act according to the character of the Gods. Hastabrata also became a benchmark for leadership at that time. Hastabrata is the name of the teaching that contains "cubits" in Javanese meaning eight and "brata" means behavior, so that Hastabrata is interpreted as eight behavior or eight characters that must be possessed by humans, especially those who are domiciled as leaders. The behavior of the Javanese people in the socio-political challenges which he formulated in his thinking as a path to humans who always improve themselves in the process. Humans are expected to know themselves about the threshold between Makhluq (limited) and Khaliq (unlimited), for example is when the head of state will definitely abdicate, as happened during the fall of Soeharto (Supadjar 2001: XII). Behavior can only be done by proceeding to become, so that people who practice it always have a process to improve themselves by doing good things to achieve eternal goals. Matters emphasized in the concept of behavior are sincerity by prioritizing harmony and harmony of nature both microcosm and macrocosm.

The source of Hastabrata's teachings turned out to be a shift, initially the sources of Hastabrata's teachings were eight characters (behavior) possessed by the Gods, namely Gods: Indra, Bayu, Agni, Surya, Yama, Anila, Kuwera, and Baruna. Among the eight Deities mentioned above there is a difference between the teachings of Javanese Hastabrata and Hindu Hastabrata there is the character of Dewa Agni which is made an example for a leader and there is no character of Dewa Brama. In accordance with the change in the way of Javanese thinking, the orientation of the leadership character becomes shifted in the character of natural objects. The shift began when the birth of the Hastabrata teachings was published in the Sangkala chronicle. Then the role model of leadership on natural objects thickens in the socialization of Hastabrata's teachings through puppet performance, as in the teachings of Makhutarama. The nature of natural objects which became the next model of leadership are: kisma (land / earth), tirta (water), samirana (wind), samodra (ocean / ocean), candra (moon), baskara (sun) dahana (fire), and kartika (star) which is also called the nature of mountains (Tedjawirawan 1998). Meanwhile, according to Raden Ngabehi Ranggawarsita in Serat Aji Pamasa, the sources of Hastabrata's teachings are: the character of Surya or srengenge (sun); Candra character or moon (moon); Sudama character or latitude (star); Maruta character or wind (moving air); Mendhung character (rain clouds); Dahana character or geni or latu (Fire); Tirta or banyu or samodra (water) character; The nature of pratala or earth or weak (Land). The 
transformation of the attributes of the Deity into the eight natural elements themselves is recorded in the Purwa manuscript. The shift in orientation is also a shift in the use of Hastabrata teachings. If in the past Hastabrata was intended for rulers or leaders, the shift in orinetation to natural objects shows that Hastabrata's teachings have become populist teachings. The implication is not only leaders who need to get the eight attributes of the god or nature but also the entire people without exception.

The shift in orientation is inseparable from the change in mindset and belief in Javanese society. Javanese who used to be animistic and dynamistic had shifted to belief in certain religions. The characteristics of Javanese culture in the Kawalen Period, both since the time of Demak, Pajang and Mataram Islam, still maintain the Hindu-Buddhist tradition of the Majapahit period, including the traditions of animism and dynamism which are enriched and adapted to the atmosphere of Islam. In addition, keratonsentris and mystical character are also increasingly visible. Another prominent feature in Javanese culture is that it is full of symbols. This might be because Javanese people were not accustomed to abstract thinking, so all ideas were expressed in the form of more concrete symbols. Thus, everything can be a puzzle, because symbols can be interpreted in multiple ways. Perhaps this also relates to mystical teachings which are very difficult to explain in a methok (straightforward), so that Javanese culture is symbolically expressed or with multiple meaningful expressions (Simuh 2019).

Puppet performances with the play "Wahyu Makutharama" Ki mastermind Anom Suroto (2009) explained that "piwulang sinebut revelation because of the high degree contained in the piwulang tan prabeda revelation nugrahaning Gusti kang akarya jagat" which means that the teachings of Hastabrata are called revelations because of the high degrees contained in the teachings of prabeda tan prabeda nugrahaning Gusti kang akarya jagat so that it is considered the same as a gift from God who created the universe.

Hastabrata's teachings do not only exist in the play of Wahyu Makutharama which illustrates the teachings of Begawan Kesawasidi which is a transitional form from Bathara Kresna to Harjuna who was then imprisoned to seek revelation. But this teaching is also implied in serat Dewaruci. When Bima traveled in search of the holy water of Perwitasari and met Dewaruci, in Guagarba Bima saw the great ocean with no edge, very far away and unlimited space. Bima doesn't know keblat, there is no sun, and what is found is awang-uwung (emptiness). The emptiness is a symbol of God realized by Bima, and in essence it comes from God. Dewaruci's words to Bima about one flame with eight colors, namely: pink, purple, green, gray, blue, yellowish red, orange, white rather green means that the first flame is the flame of the soul. While the eight-color ray, is a ray of blood, like a flower and its fragrance, its appearance and color, appearance and flame (urub). Urub is urip (life), color is color (curtain), the truth is water. When reversed it becomes: banyu urip (living water).

The eight colors are in essence a reflection of the eight characteristics found in the universe that can be responded to by the senses. The eight properties contained in the universe are called "Hasthabrata", meaning eight main practices, consisting of: the sun, moon, stars, earth, water, sea, wind, and fire. In the heart of Hastabrata's human heart as strength, beauty, uncleanness, patience, purity, capacity, accuracy and serenity (S.P Adhikara 2011:40). The eight colors or Hastabrata describe the attributes of the Almighty God contained in his creation.

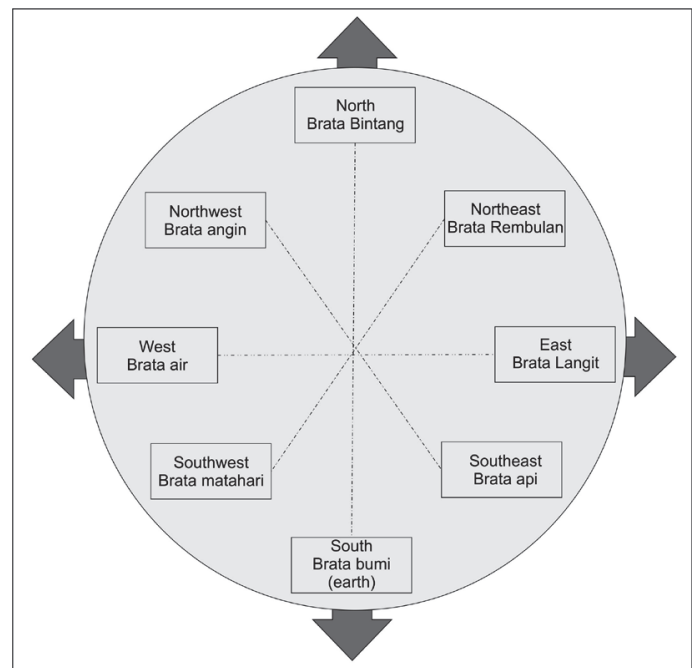

Figure 6: Concept Hastabrata “Kepemimpinan sejati” (True leadership). Purnengsih, 2020.

Soetarno (2020) said that, "The event when Bima saw eight colors (cubits of color), was a reflection of the eight characteristics found in the universe. 8 brata leadership teachings or the promise of a true leader, later called kemudian Hastabrata' $(8+1)$. Hasta color symbolizes the unity of microcosm and macrocosm. The cubits of color in Javanese culture are also called Astha Brata. Bima's journey to get Astha Brata in the Bimasuci story is a cosmic understanding. Bima and Dewaruci are symbols of "me" and basic divine powers, while Hasthabrata 
is a symbol of the power of the universe which forms the basis of human numinous beliefs. Hasthabrata which is implied in the play of Bimasuci and in the play of Wahyu Makutharama is essentially a teaching of leadership for the community and the holders of power.

Yasadipura I (1729-1803) from Kraton Surakarta in (Adriansyah 2011) said that the sources of Hastabrata teachings are: mahambeg mring kisma (imitating the nature of the earth), mahambeg mring warih (imitating the nature of water), mahambeg mring samirono (imitating the nature of the wind), mahambeg mring kisma (imitating the nature of the earth) candra (imitating the nature of the moon), mahambeg mring surya (imitating the nature of the sun), mahambeg mring samodra (imitating the nature of the ocean / ocean), mahambeg mring wukir (imitating the nature of mountains), mahambeg mring dahono (imitating the nature of fire). The teaching of hasthabrata can be explained as follows:

1. Brata Matahari (mimicking the nature of the sun). The sun emits heat rays as a source of life that makes all creatures grow and develop. A leader must be able to grow and develop the life force of his people, and provide life and provide continuous enthusiasm for those led.

2. Brata Candra (nature of the moon). The moon radiates light in the darkness of the night. This means that a leader must be pleasant, able to foster enthusiasm and beautiful expectations when times of grief and joy, and provide lighting in the dark.

3. Brata Kartika (star nature). Stars emit beautiful glow and light in the sky so they can be used as a guide. A leader must give an example led by doing good so that it can be a role model or training that is led.

4. Brata Hima (cloud properties). Thick clouds cause rain. This means that a leader must be authoritative and his actions must be able to provide welfare for his subordinates.

5. Brata Samirana (nature of the wind). The wind can always go everywhere without distinguishing places and filling empty spaces. This means that a leader must be close to his people and all his policies must be propeople, so that his leadership can be felt at the grass root level.

6. Brata Samodra (nature of the sea or water). The sea is very wide and has an infinite load. A leader must be visionary, honest, accept criticism, act fairly, and be able to provide solutions to the difficulties encountered.

7. Brata Dahana (nature of fire). Fire has the ability to burn away and scorch everything that comes into contact with it. A leader must have the courage to uphold justice and truth indiscriminately, and all problems can be resolved thoroughly.

8. Brata Bantala (nature of soil). Land has strong and generous characteristics. This means that a leader must be humble, tepira salira, honest, selfless and willing to reward those who have meritorious.

The teaching of Hastabrata gives cosmic awareness that the world with all its contents contains lessons for humans who want to reflect and examine it. The Javanese leadership norm is known by the expression of the words of the queen pandita being hit by wola-wali. It means that a leader must be consistent in carrying out and realizing what is said. Javanese people refer to it as a person who is businesslike, who is steadfast in keeping with promises, not following misleading passions. So that a leader can carry out his true leadership function and grace for the universe as a manifestation of "mamayu hayuning bawana" which in Islamic teachings is known as "rahmatan lil'alamin". During the New Order era, the teachings of Hastabrata became a reference in managing government institutions and as a guide in moving the community.

\section{Conclusion}

Bima's journey (as personification) meets Dewaruci (inter-personification), in seeking holy water perwitasari (living water), and obtaining wirid in true science, cultural teachings about seeking true knowledge, which has rooted in the lives of Javanese people in the form of contemplation philosophy, in detail will be explained:

First: Bima's Journey from "Alam Sakala to Alam Niskala" The teachings of Javanese people in maintaining a vertical and horizontal balance in Javanese culture are known as keblat papat kalima pancer, also called" the world of time ", known as the four-dimensional classification of space, patterned four-eyed wind with one center $(4+1)$. Together means the whole, the basic unity of opposition to control, meaning that the unity that occurs due to differences, and differences are the basis of strength that must be sought as a balance, harmony of life by means of self-control

Second: Getting the teachings of "Hastagina" in the concept of Mandala. Bima's journey in finding "Holy Water Perwitasari" (water of life) associated with the number $9(8+1)$, in accordance with the teachings of Javanese culture, the teachings of "Astagina". Bima's fame in finding holy water "Perwitasari" (water of life), obtained wirid in true science, can be used as an indication of how this business has indeed taken root in the lives of Javanese people. And Getting the teachings of "Hasta Brata" in the concept of Mandala. The teaching of the hastabrata $(8+1)$ is the relationship between himself (the microcosm) and the 8 good qualities which must be carried out or carried out. Hastabrata was then a teaching believed by the Javanese people to be related to true leadership. A true leader is when he exercises at least 8 good qualities ( 8 brata). 


\section{References}

Adriansyah. 2011. "Adriansyah, 2011. Perilaku Ajaran Hasta Brata (Wahyu Makkutha Rama) (Online) Http://Buday Aleluhur.Blogspot.Com/2011/12/per Ilaku-Ajaran-Hasta-Brata-Wahyu. Html Diakses Tanggal 19 Agustus 2013.” Jumantara.

Arguelles. 1972. Mandala. Boelder and London: Shambala.

Ciptoprawiro, Abdullah. 1986. Filsafat Jawa. Jakarta: Balai Pustaka.

Dharsono. 2007. Estetika. Bandung: Rekayasa Sains.

—. 2016. Kreasi Artistik, Perjumpaan Tradisi Modern Dalam Paradigm Kekaryaan Seni”. Surakarta: LPKBM Citra Sain.

Echols, John M., and Theodor G. Th. Pigeaud. 1969. "Literature of Java. Catalogue Raisonné of Javanese Manuscripts in the Library of the University of Leiden and Other Publications in the Netherlands. Vol. I. Synopsis of Javanese Literature, 900-1900 A. D.Literature of Java. Catalogue Raisonne of Javanese Manuscripts in the Library of the University of Leiden and Other Publications in the Netherlands. Vol. I. Synopsis of Javanese Literature, 900-1900 A. D." Journal of the American Oriental Society 89 (3): 647. https://doi.org/10.2307/596639.

Geertz, Clifford. 1973. The Interpretation of Culture. New York: Basic Book, Ink.

Hadiwijono, Harun. 1974. Kebatinan Jawa Dalam Abad 19. Jakarta: BPK Mulya.

Kartosoejono. 1950. Kitap Wali Sepuluh. Kediri: Bookhandel tan Khoen Swie.

Ki Anom Suroto. 2009 Pagelaran Wayang Kulit Lakon Wahyu Makutharama (online) http://jamanse mana.com/2009/06/24/wa hyu-makutharama/ diakses tanggal 20 Juni 2020

Marsono. 2010. "Amanat Kepemimpinan Ideal Asthabrata Dalam Serat Rama Jasadipura (Analsis Intelektual)." Jumantra 1(2).

Poespoprodjo. 1991. Interpretasi: Beberapa Catatan Pendekatan Filsafatinya. Bandung: Penerbit Remadja Karya CV. Bandung.

S.P Adhikara. 2011a. Analisis Serat Bimasuci. Jakarta: Yayasan ’Institut Indonesia. - 2011b. Dewaruci. Jakarta,: Institut Teknologi Bandung.

Simuh. 2019. Sufisme Jawa, Transformasi Tasawuf Islam Ke Mistik Jawa. Edited by Candra Gautama. 1st ed. Jakarta,: Bentang Budaya.

Subagyo, Rahmat. 1981. Agama Asli Indonesia. Jakarta: Sinar harapan dan Yayasan Cipta Loka Caraka.

Sumardjo, Jacob. 2003. Memahami Seni. Bandung: Diklat Pascasarjana ITB.

Supadjar, Damardjati. 2001. Mawas Diri. Yogyakarta: MedPrint Offset.

Sutopo. 2002. Metodologi Penelitian Kualitatif (Dasar Teori Dan Terapannya Dalam Penelitian).

Tedjawirawan. 1998. "Nilai Susastra Dan Kandungan Filosofis Dalam Wahyu Makutha Rama', Dalam Marsono Dkk., 'Nilai Susastra Dan Kandungan Filosofis Wayang'. Laporan Penelitian Kerjasama Antara: Fakultas Sastra UGM Dengan Senawangi.” Jakarta.

Wahyati, Pradipta. 1998. Ajaran Kepemimpinan Asthabrata, Dalam Sarworo Soeprapta Dan Sri Harti Wiyastuti, Ramayana, Transformasi, Pengembangan Dan Masa Deannya. Yogyakarta: LSJ \& FPBS IKIP.

Jasadipoera, R.Ng. 1925. Serat Rama, Djilid III. Bale Poestaka: Weltevreden.

\section{Resources:}

Darmoko. (th). Javanese Culture Expert and Lecturer at the Faculty of Cultural Sciences, University of Indonesia, interview on 10 June 2020 .

Soetarno. (th). Javanese Culture Expert and Lecturer at the Indonesian Institute of Art, Surakarta. interview on June 25, 2020.

\section{Biography \\ Iis Purnengsih, S.Sn.,M.Sn}

Born, Bandung, February 03, 1979

Lectur Faculty of Fine Arts and Design, University of Indraprasta PGRI Jakarta

Doctoral program student of Arts, Institut Seni Indonesia Surakarta, Indonesia

Visual Communication and Humanities Expertise Group

\section{Prof. Dr. Dharsono, M.Sn. (Sony Kartika)}

Professor of Art Aesthetics

Obtained a doctorate degree at the ITB Postgraduate School 2005.

ISI Surakarta FSRD Fine Arts Lecturer. Postgraduate Lecturer at ISI Surakarta,

Visiting lecturer (extraordinary) at the Post-graduate degree at Trisakti University Jakarta, Post-graduate ISI Padang Post-graduate UNNES Semarang. Chairman of the Institute for the Study and Conservation of Archipelago Culture 
Dr. Agung Eko Budiwaspada M.Sn.

Visual Communication and Multimedia Expertise Group

Faculty of Fine Arts and Design, Institut Teknologi Bandung, Jawa Barat, Indonesia

Dr. Suyanto, S.Kar., M.A.

Faculty of Pedalangan Department, Institut seni Indonesia, Surakarta, Indonesia 